\title{
Books, Scribes, and Cultures of Reading in the Shepherd of Hermas
}

\author{
by TRAVIS W. PROCTOR
}

Wittenberg University, Springfield, Ohio

E-mail: proctort@wittenberg.edu

In this article, I analyse how the Shepherd of Hermas constructs an ancient Christian reading culture through concurrent portrayals of Christian reading, copying and book production. I argue that, by portraying its protagonist Hermas as an idealised reader, scribe and auditor, the Shepherd constructs an early Christian reading culture that authenticates Hermas's role as prophet, activates the textual dissemination of the Shepherd and ritualises the practice of Christian auditory 'reading'. The article closes with 'Hermas the freedman', which considers how Hermas's self-presentation as a formerly enslaved person may have connections to the Shepherd's centralisation of ancient reading cultures.

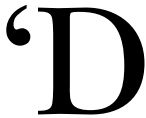

o you want to hear me read?' 'So begin the revelations of the Shepherd of Hermas, a second-century Christian prophetic work. The question, directed from an angelic mediator to Hermas, the central figure and presumed author of the text, presages a larger theme within the work: the importance of reading, as well as writing and book production more generally, in Hermas's receipt and transmission of prophetic knowledge. Yet, despite the Shepherd's centralisation of book reading and dissemination, previous treatments of the Shepherd have

The author wishes to thank those who provided feedback on previous versions of this article, including audiences at the 2017 North American Patristics Society meeting, the 2019 Society of Biblical Literature meeting and especially fellow participants at the 2020 conference 'Cultures of Reading in the Ancient Mediterranean' at Duke University.

1 Shepherd of Hermas, Vision 1.4.3. Here and throughout Greek text and English translation is that of Bart D. Ehrman, The Apostolic Fathers, Cambridge, MA 2005, ii. 
emphasised Hermas's illiteracy (or limited literacy, at the least) and poor writing style. Peter Lampe notes that modern readers have described the Shepherd's writing as 'clumsy', 'disorderly', 'contradictory', 'childish', 'crude' and 'awkward', and Lampe himself concludes that Hermas 'possessed a rudimentary literary ability'.2 Along similar lines, William Jerome Wilson attributes to Hermas the following characteristics: 'possessed of little education', 'no great intellectual endowment', lacking 'penetrating intelligence' and possessing an 'unsystematic mind'.3

The persistent emphasis on Hermas's illiteracy or lack of intelligence has had a significant impact on the text's reception among scholars, as many have interpreted it as an unsophisticated reflection of Hermas's Roman Christian context. J. Christian Wilson argues, for example, that 'the Shepherd of Hermas ... tells us more about the daily living and thinking of ordinary Christians at the turn of the second century than any other document'. ${ }^{4}$ James Jeffers similarly asserts that 'Hermas' very ordinariness makes quite probable the representative nature of his work.'5 What follows explores how turning to the Shepherd's discussion of books and reading culture might call into question this emphasis on the 'ordinary' and 'representative' nature of the Shepherd, and instead bring attention to how the text constructs and prescribes the type of reality that it works to enact. A major part of the Shepherd's self-presentation entails depictions of reading, copying and book production, which work in tandem to construct an idealised Christian reading culture centred on the dissemination and public reading of revelatory works. I argue, moreover, that many of the elements that contemporary scholars have cited as revealing of Hermas's intellectual shortcomings are in fact part of the author's self-authentication and self-positioning within the Shepherd's idealised Christian reading culture.

This analysis builds on the work of the classicist William A. Johnson, who has argued for analysing ancient practices of reading as part of their respective 'reading cultures', which Johnson defines as 'the cultural construct that underpins group and individual behaviors in a reading event'. ${ }^{6}$ Johnson emphasises that reading practices must be analysed as

${ }^{2}$ Peter Lampe, From Paul to Valentinus: Christians at Rome in the first two centuries, Minneapolis, MN 2003, 233.

3 William Jerome Wilson, 'The career of the Prophet Hermas', Harvard Theological Review xx (1927), 21-62 at pp. 27, 43, 45.

$4 \mathrm{~J}$. Christian Wilson, Five problems in the interpretation of the Shepherd of Hermas, Lewiston, NY 1995, 2.

5 James S. Jeffers, Conflict at Rome: social order and hierarchy in early Christianity, Minneapolis, MN 1991, 114 .

${ }^{6}$ William A. Johnson, Readers and reading culture in the high Roman Empire: a study of elite communities, Oxford 2010, 11 n. 20. 
part of 'the negotiated construction of meaning with a particular sociocultural context', 7 while highlighting how ancient texts played important roles 'as a part of the negotiated construction of a community that centered around literary texts'. ${ }^{8}$ Following Johnson's lead, the Shepherd of Hermas will be examined for how it constructs Christian practice and identity as centred on the writing, reading and production of authoritative texts. This examination consists of three parts, correlating to the roles taken on by Hermas in the Shepherd: Hermas the reader; Hermas the scribe; and Hermas the auditor. Through these interrelated portrayals, the Shepherd constructs an early Christian reading culture that authenticates Hermas's role as a prophetic scribal transmitter, activates the textual dissemination and reception of the Shepherd and ritualises the process of auditory 'reading' by which Hermas envisions his audience engaging with his work. The article concludes with 'Hermas the freedman', which considers how Hermas's self-presentation as a formerly enslaved person may have connections to the Shepherd's centralisation of textual expertise in the revelation of divine knowledge.

\section{Hermas the reader}

Throughout the Shepherd, the process of reading books forms an integral part of how both Hermas and his heavenly interlocutors transmit prophetic knowledge. Hermas's first revelatory partner, the elderly woman, appears 'dressed in radiant clothes and holding a book [ $\beta$ i $\beta \lambda$ iov] in her hands'. ${ }^{9}$ The woman then begins to reveal 'great and amazing matters', which form the foundation for Hermas's first revelations. ${ }^{10}$ As part of Vision 2, Hermas again encounters the elderly woman: 'When I arose from prayer I saw across from me the elderly woman I had seen the year before,

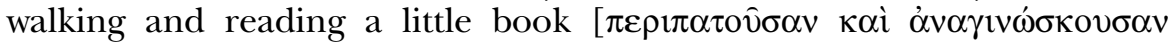
$\beta i \beta \lambda \alpha \rho i \delta$ iov].' ${ }^{11}$ In both of his initial visions, therefore, Hermas portrays heavenly figures as possessing and reading books. In this regard, Hermas stands alongside other 'bookish' ancient apocalyptic texts that forefront the importance of the written word in the transmission of heavenly knowledge. ${ }^{12}$ Distinctive to the Shepherd is that it identifies its revelatory figure with the cultic community writ large: according to a later revelation, the 'elderly woman from whom [Hermas] received the little book' is in fact

7 Ibid. 12, cf. his 'Toward a sociology of reading in classical antiquity', American Journal of Philology cxxi (2000), 593-627 at p. 603.

9 Vision 1.2.2.

8 Idem, Readers, 16.

${ }^{12}$ For examples of book-centred revelatory texts see especially $I$ Enoch, the Book of Jubilees and the Book of Revelation. For discussion see Harry Gamble, Books and readers in the early Church, New Haven 1995, 80, and below. 


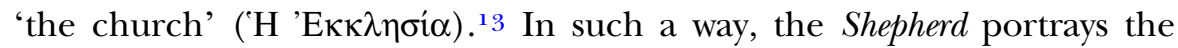
Christian Church, and thus the community as a whole, as a bibliophilic purveyor of textualised knowledge, with special access to a 'heavenly archive' of revelatory texts. ${ }^{14}$

It is perhaps surprising, then, that the Shepherd portrays its protagonist (and apparent author), Hermas, as an unskilled reader. After the lady asks Hermas to 'announce these things [i.e. the contents of the little book] to the ones chosen by God', Hermas admits that he cannot remember all the information. Hermas requests that she lend him the book to make a copy, and she accedes. ${ }^{15}$ 'I took it and went away to another part of the field', Hermas explains, 'where I copied the whole thing, letter by letter, for I could not distinguish between the syllables.' ${ }^{16}$ Hermas's failure at distinguishing the syllables is likely a reference to ancient educational approaches to the learning of reading: beginning readers acquired literacy by learning potential syllabic sets of letters (e.g., ba, be, bi, bo, bu, ca, ce, etc.). ${ }^{17}$ Hermas thus presents himself as being unable to perform the basic reading task of perceiving the syllables and making meaning of the text. ${ }^{18}$ But to what end?

Previous commentators have frequently seen in this passage evidence that Hermas was perhaps only 'basically literate'. ${ }^{19}$ Such interpretations fail to account for the broader narrative arc of the Shepherd. Shortly after Hermas's failed reading of the little book, he explains his eventual ability to understand its contents: 'Fifteen days later, after I had fasted and asked the Lord many things, the meaning of the writing was revealed to me. ${ }^{20}$ Hermas claims, therefore, that his understanding of the book emerged through repeated prayer and a lengthy fast, which resulted in a heightened level of spiritual discernment. ${ }^{21}$ As such, the Shepherd reveals that Hermas's initial shortcomings as a reader were not due to a lack of functional literacy, but insufficient spiritual preparation for understanding heavenly texts.

13 Vision 2.4.1.

${ }^{14}$ My language of 'heavenly archive' here draws on the work of Eva Mroczek, The literary imagination in Jewish antiquity, Oxford 2016, 18.

15 Vision 2.1.3.

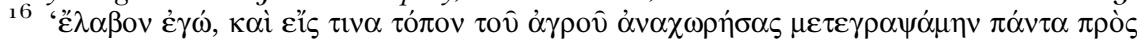

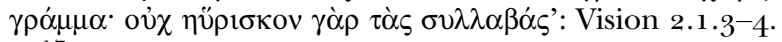

${ }^{17}$ Johnson, Readers, 27; Raffaella Cribiore, Gymnastics of the mind: Greek education in Hellenistic and Roman Egypt, Princeton 2005, 173.

${ }^{18}$ Kim Haines-Eitzen, Guardians of letters: literacy, power, and the transmitters of early Christian literature, Oxford 2000, 62; Cribiore, Gymnastics, 174-5.

19 On Hermas as 'basically literate' see Carolyn Osiek, Shepherd of Hermas: a commentary, Minneapolis, MN 1999, 52; cf. Norbert Brox, Der Hirt des Hermas: ̈̈bersetzt und erklärt, Göttingen 1991, 91 . ${ }^{20}$ Vision 2.2.1.

${ }^{21}$ On the connections between fasting and revelation elsewhere in the Shepherd see Vision 3.1. 
Hermas's initial 'illiteracy' and eventual comprehension of the heavenly book serves a two-fold purpose. First, the two-part revelation places textual processes (i.e., copying and reading) at the centre of divine revelation. It is notable, for example, that in the second scene of Hermas's revelation, when he is able to discern the meaning of the book, no revelatory figure is present. While Norbert Brox argues that this demonstrates that the 'revelation apparatus' is 'secondary' to the text, ${ }^{22}$ I would propose instead that it centralises the 'revelation apparatus' within the text itself. Put another way, the primary purpose of the revelatory figures is in service of the conveyance or creation of textualised knowledge; when such textual knowledge is available (for example, through copying and reading), the revelatory figure is superfluous.

Second, the Shepherd constructs a culture of reading that cannot be reduced to pure literacy (i.e., the discerning and understanding of syllabic units), but which must be combined with proper spiritual practices to comprehend heavenly knowledge. This connection is encountered again later in the text, when the Shepherd asks Hermas, 'What did you have for dinner?' Hermas responds, 'All night long, Lord ... I dined on the words of the Lord.' 23 With this response, Hermas again connects fasting-here indicated by Hermas's apparent eschewal of a meal - with revelation and receipt of divine words (whether through prayer or reading). In this way, Hermas constructs proper 'reading' of divine words as a multi-step process, one completed through an interconnected set of ritualised practices that promoted spiritual perspicacity. The Shepherd's portrayal of Hermas's initial reading failures, therefore, serves the broader goal of constructing a particular culture of reading, centred on the synthesis of Christian reading, prayer and fasting.

Within this Christian reading culture, the Shepherd positions Hermas as an idealised reader and interpreter. Hermas successfully completes the ritual actions that unlock the divine secrets of the heavenly book. In Vision 3, moreover, the revelatory figure tells Hermas that 'these things have not been revealed for your sake alone; for you are to show $[\delta \eta \lambda \omega \sigma \varepsilon 1 \varsigma]$ them to all the others', ${ }^{24}$ thus identifying him as an authoritative expositor of heavenly knowledge. The woman later makes plain that Hermas's role will comprise an exegetical component, commanding

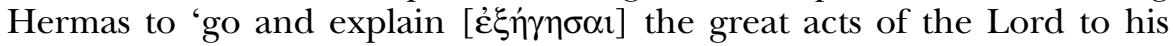
chosen ones'. ${ }^{25}$ The woman's intertwining of reading and interpretation fits well with what is known about ancient reading practices. Ancient texts, including those produced by Christians, were recorded in scriptio continua, blocks of undifferentiated letters largely lacking in reader's aids (for

22 Brox, Der Hirt, 97-8.

23 Parable 9.1 1.8-9.

24 Vision 3.8.10-1 1.

${ }_{5} 5$ Vision 4.2.5. For more on Hermas's evolution as an authoritative interpreter see Patricia Cox Miller, Dreams in late antiquity, Princeton 1994, 133-4, 142, 146. 
example, spacing, punctuation, accents). In public reading settings, therefore, the reader held the extra responsibility of discerning the appropriate division of words and clauses and conveying the meaning of the text properly. ${ }^{26}$ 'To engage in reading a text', Kim Haines-Eitzen surmises, 'necessarily involves one in the practice of interpreting a text.' ${ }^{27}$ Hermas's charge to 'show' and 'explain' to fellow Christians the contents of the heavenly book, therefore, situates him as an authoritative reader and interpreter for his community. In this regard, it is notable that the Shepherd repeatedly portrays Hermas as an inquisitive interlocutor who persistently seeks to understand his visions. ${ }^{28}$ While Hermas's initial foray into the heavenly archive is not without its difficulties, therefore, the Shepherd none the less constructs a broader reading culture wherein heavenly revelation and Christian ritual practice combine to form a foundation for idealised Christian reading practices. Through his writing, reading, questioning and interpreting, Hermas tracks for his audience an appropriate evolution from beginning reader to advanced interpreter, ultimately becoming a reader who does not fail to 'read the syllables'. ${ }^{29}$

\section{Hermas the scribe}

Equally important to Hermas's role as prophetic mediator is his practice of transcribing heavenly knowledge. This theme is demonstrated in the second vision that Hermas receives from the elderly woman. Hermas asks to borrow the woman's little book so that he may 'make a copy' $(\mu \varepsilon \tau \alpha \gamma \rho \alpha \dot{\psi} \psi \omega \mu \alpha \imath) .3^{\circ}$ The lady responds by granting Hermas's request, on one condition: 'Take it ... and then return it to me.' ${ }^{11}$ Hermas explains, as noted previously, that he then 'copied the whole thing, letter by letter, for I could not distinguish the syllables. And then, when I completed the letters of the book, it was suddenly seized from my hand; but I did not see by whom'.$^{32}$ Beyond initiating Hermas's development as an authoritative reader, this passage functions to underwrite Hermas's unique authority as a prophetic scribe, while also positioning scribal activity and private book networks as foundations of a broader Christian reading culture. First, Hermas's letter-by-letter copying, occasioned by his initial inability to make sense of the 'little book', situates textual copying as an act that

\footnotetext{
${ }^{26}$ Johnson, Readers, 130, 169; cf. Dan Nässelqvist, Public reading in early Christianity: lectors, manuscripts, and sound in the oral delivery of John I-4, Leiden 2016, 27.

${ }^{27}$ Haines-Eitzen, Guardians of letters, 111.

${ }^{28}$ Osiek, Shepherd of Hermas, 86. See also the discussion below on Hermas's inquisitiveness.

${ }_{29}$ The latter phrasing is borrowed from Miller, Dreams in late antiquity, $14^{6-7}$.

$3^{0}$ Vision 2.1.3. ${ }^{31}$ Ibid. 
carries the potential to communicate divine knowledge, while simultaneously portraying Hermas as a reliable copyist who ensures that his copied texts are accurate through detailed transcription. 33 Thus, while Hermas might initially appear unable to handle the divine revelations, he none the less emerges as an effective medium of revelatory knowledge through his ability to copy heavenly books for earthly consultation. 34

The centralisation of scribal activity emerges even more clearly when the Shepherd is compared to comparable ancient representations of the transcription of heavenly knowledge. While the Shepherd shares with other ancient apocalypses a process of revelation through textualised knowledge, it is unique in the handing over of the heavenly text for copying by a human scribe; in other apocalypses, the text is dictated orally (Revelation i.19; ii.1), consumed for later public preaching (Ezekiel ii.9-10) or memorised for later transcription (Jubilees xxxii.21-6).35 Hermas, by contrast, admits his inability to memorise or understand the material, and so must resort to borrowing and transcribing the book 'letter by letter'. In this way, the Shepherd constructs the process of divine revelation as a textual phenomenon from beginning to end, with the transcriptional practice of the careful scribe at the forefront.

The portrayal of Hermas as a prophetic scribe surfaces elsewhere in the Shepherd. In Hermas's fifth vision, which serves as an introduction to the commandment and parable sections, the Shepherd (as part of his first appearance as a revelatory figure) orders Hermas to 'write my commandments and parables' and additionally to 'write the other things just as I show them to you'. ${ }^{6}$ Hermas indicates his successful completion of the task: 'And so I wrote the commandments and parables, just as he commanded me.' 37 The vision closes with a summary of Hermas's transcriptional task: 'The shepherd, the angel of repentance, thus commanded me to write all these things. ${ }^{9}{ }^{8}$ In the span of just a few verses, then, Hermas's charge to write the commandments and parables is repeated four times, underscoring the importance of transcription to Hermas's revelatory programme. 39 Hermas later similarly claims that he "wrote the commandments and parables of the shepherd', $4^{\circ}$ and, again, that he 'had written out' the additional book of revelations that he received from the Shepherd..$^{1}$ In this way, the Shepherd repeatedly presents itself as a

33 Jonathan E. Soyars, The Shepherd of Hermas and the Pauline legacy, Leiden 2019, 33.

34 Ibid; Haines-Eitzen, Guardians of letters, 21-2, 36-7.

35 Osiek, Shepherd of Hermas, 52; Haines-Eitzen, Guardians of letters, 37; cf. Annette Yoshiko Reed, Demons, angels, and writing in ancient Judaism, Cambridge 2020, 302; Mroczek, Literary imagination, 122-3, 143, 151-4; Gamble, Books and readers, 80; and Wolfgang Speyer, Bücherfunde in der Glaubenswerbung der Antike, Göttingen 1970.

${ }_{36}^{6}$ Vision 5.5. 37 Vision 5.6. 38 Vision 5.7.

39 J. Reiling, Hermas and Christian prophecy: a study of the eleventh mandate, Leiden 1973 , 161; Osiek, Shepherd of Hermas, 86, 96-7. $\quad 4^{\circ}$ Parable 9.1.1-2. $\quad 4^{1}$ Parable 1o.1.1. 
self-reflexive written work, dependent on the transcription of a revelatory scribe. $4^{2}$

Throughout the Shepherd, Hermas's heavenly interlocutors command that he share his textualised revelations with the broader Christian community. The elderly woman orders Hermas, for example, to 'make these words known to all your children and your wife' 43 and 'not stop speaking in the ears of the saints'. 44 Such 'commission-scenes' are frequently followed by a switch in the narrative from address to Hermas (in the second person singular) to address to an unnamed audience (in the second person plural), thus suggesting that these passages were to serve as part of paraenetic instruction for the broader Christian community. 45 Hermas's textual transmission of heavenly knowledge, therefore, seems destined for oral reading and interpretation in a group setting. $4^{6}$ Carolyn Osiek has previously argued that such commission scenes indicate that the Shepherd is part of 'a basically oral culture'. 47 Osiek's analysis draws on the work of the anthropologist Walter Ong, who posits a strong distinction between 'literate' and 'oral' cultures. $4^{8}$ Osiek argues that the Shepherd consists of 'underlying oral patterns', such as 'additive' or 'redundant' characteristics, which are to be contrasted with the productions of 'literary cultures'.49 To substantiate this hypothesis, Osiek downplays the importance of texts within the Shepherd's narrative:

Hermas' authority is confirmed in writing, but most of the process as described within the narrative is oral: the opening scenes of the visions use personal figures to give oral instruction and communication; the woman church reads aloud to Hermas (Vis. 1.3.3-4), and only a year later does he receive a written text, which requires two weeks of prayer and fasting from him to be able to read $(2.1 .3-4 ; 2.2 .1)$. The first written text is actually quite brief $(2.2 .2-3.4)$. At the appearance of the Shepherd, Hermas is commanded to write what he receives by oral dictation for the purpose of oral proclamation. $5^{\circ}$

$4^{2}$ It is notable that, in this instance, Hermas seemingly transcribes through dictation, a practice common in ancient book copying and which can be found in other ancient apocalypses: cf. Revelation i.19; ii.1.

44 Vision 4.3.6; cf. Vision 2.2.6; Vision 3.8.1 1; Parable 8.11.1.

45 Reiling, Hermas and Christian prophecy, ${ }_{16} 5^{-6}$. For further discussion and citation of these scenes see below.

$4^{6}$ Steve Young, 'Being a man: the pursuit of manliness in the Shepherd of Hermas', Journal of Early Christian Studies ii/3 (1994), 237-55 at p. 242. For more on this see below.

47 Carolyn Osiek, 'The Shepherd of Hermas in context', Acta Patristica et Byzantina viii (1997), $115^{-34}$ at p. 127 .

$4^{8}$ Ibid.

49 Idem, Shepherd of Hermas, 13, and 'Shepherd of Hermas in context', 122-7; cf. her 'The oral world of early Christianity in Rome: the case of Hermas', in Karl P. Donfried and Peter Richardson (eds), Judaism and Christianity in first-century Rome, Grand Rapids, Mi $1998,15^{1-72}$. 
While Osiek correctly highlights the oral components of Hermas's revelatory process (e.g., dictation, oral proclamation), her analysis oddly discounts the fact that texts are at the centre of each of the 'oral' practices that she cites here: the woman reads aloud from a book, Hermas receives and copies a written text for his revelations, Hermas then reads the written text, and the basis for Hermas's proclamations will again be the written text that he copies.

Osiek's stark dichotomy between oral and literate cultures, therefore, is ill-suited for analysing the Shepherd's constructions of divine revelation. Indeed, there was extensive overlap between textual and oral cultures within ancient Mediterranean societies. ${ }^{5}{ }^{1}$ Oral dictation was often part of the process of textual copying, and ancient readers frequently encountered written texts through oral reading performances; oral proclamations, on the other hand, often gained wider distribution through their textualisation. $5^{2}$ 'Both in production and consumption', Matthew Larsen concludes, 'it was difficult to separate the oral and the written.'53 The fluidity between oral and written cultures can help to explain, therefore, why the Shepherd clearly situates oral proclamations as an important part of an otherwise text-focused revelatory process. 54

The close interconnection between textualised knowledge and oral proclamation is visible again in Vision 2. There, the elderly woman asks if Hermas has 'already given the book to the presbyters', clearly implying that this was an expectation of Hermas's prophetic activity. 55 The woman then informs Hermas that she will be adding to his revelations and that he should make sure to disseminate copies of the book more widely: 'And so, you will write two little books, sending one to Clement and the other to Grapte. Clement will send his to the foreign cities, for that is his commission. ${ }^{5}{ }^{6}$ With this directive, the woman charges Hermas with using his initial copy as the Vorlage for the production of several books. First, he is to make two separate copies for Clement and Grapte. Grapte 'will admonish the widows and orphans', seemingly referencing a textbased liturgical reading and interpretation for a select group of Christians. 57 Clement, on the other hand, 'will send his to the foreign cities'; it is likely that the woman here is suggesting that Clement lend his book to other Christian communities so that they can make copies of their own. In effect, this scene tasks Hermas with initiating a collection

$5^{1}$ Haines-Eitzen, Guardians of letters, 107; Reed, Demons, angels, and writing, 265.

$5^{2}$ Matthew David Larsen, 'Listening with the body, seeing through the ears: contextualizing Philo's lecture event in On the Contemplative Life', Journal for the Study of Judaism xlvii (2016), $447-74$ at p. $45^{\text {o. }}$

53 Ibid; cf. Judith M. Lieu, Christian identity in the Jewish and Graeco-Roman world, Oxford 2004, 29.

54 On the Shepherd's self-presentation as a written work see especially Parable 9.33.1; 10.1.1. 55 Vision 2.4.2. $55^{6}$ Vision 2.4.2-3. 57 Vision 2.4.3. 
of 'informal Christian scribal networks', by which several copies of Hermas's textualised revelation will be disseminated through book copying and (book-based) oral proclamations..$^{8}$

The woman's instruction here aligns well with what is known of ancient book production, copying and dissemination. Raymond Starr notes that 'Romans circulated texts in a series of widening concentric circles determined primarily by friendship'; this 'private' mode of textual dissemination, which predominated likewise among early Christians, was much more common than acquisition of copies through book shops or libraries.59 Texts in antiquity were relatively scarce; even for the wealthy and elite, tracking down copies of specific texts was difficult. ${ }^{60} \mathrm{~A}$ bookhunting expedition was typically only successful if one happened to have a friend who possessed a copy, as well as the resources or requisite skills to make a copy. For its part, the Shepherd constructs a Christian reading culture modelled on such private book networks, and so establishes both the conceptual underpinning and practical means by which the transmission of heavenly knowledge should take place. ${ }^{61}$ In doing so, the Shepherd forestalls the problem of textual scarcity by establishing a private network of lenders and copyists and preemptively saturating Christian scribal circles with copies of Hermas's 'little book'.

Hermas's network of Christian lenders and copyists is an imitation of its heavenly counterpart. Recall that in Vision 2, Hermas encounters the elderly lady reading a 'little book' ${ }^{62}$ Hermas asks that the lady give him the book to make a copy; 'Take it', she responds, 'and then return it to me. ${ }^{6} 3$ Hermas takes the book and copies it, before an unknown figure takes it back. ${ }^{6}{ }_{4}$ Hermas here presents what would have been the standard method of copying within a private book network: a friend lends a book to another, the borrower then makes a copy before returning the original. By portraying these aspects of ancient reading culture as part of the process of divine revelation, the Shepherd constructs a divine/human culture of

$5^{8}$ Geoffrey Smith, Guilt by association: heresy catalogues in early Christianity, Oxford 2015, 77. On this passage see also Michael J. Kruger, 'Manuscripts, scribes, and book production within early Christianity', in Stanley E. Porter and Andrew W. Pitts (eds), Christian origins and Greco-Roman culture: social and literary contexts for the New Testament, Leiden $2013,15^{-40}$ at p. 35 .

59 Raymond J. Starr, 'The circulation of literary texts in the Roman world', Classical Quarterly xxxvii (1987), 213-23 at p. 213 . On Christian book networks see Gamble, Books and readers, 108, and Haines-Eitzen, Guardians of letters, 82.

6 o Johnson, Readers, 92-3.

${ }^{61}$ Gamble, Books and readers, 1 og; cf. Jörg Rüpke, 'Two cities and one self: transformations of Jerusalem and reflexive individuality in the Shepherd of Hermas', in Jörg Rüpke and Gregory D. Woolf (eds), Religious dimensions of the self in the second century $C E$, Tübingen 2013, 49-65 at p. 51, and Alexander Weiss, 'Hermas' "biography": social upward and downward mobility of an independent freedman', Ancient Society xxxix (2009), 185-202 at p. $192 . \quad 62$ Vision 2.1.3. ${ }^{63}$ Ibid. ${ }_{64}^{6}$ Vision 2.1.4. 
reading and book dissemination, comprising a transmundane network of lenders, readers and scribes.

The Shepherd hints that there are several books in the heavenly 'archive'. Within Hermas's first two visions, for example, the elderly lady is portrayed as reading two different books: first, a lengthy scroll [ $\beta$ i $\beta \lambda$ iov], then a 'little book' $[\beta \uparrow \beta \lambda \alpha \rho i \delta$ iov $] .{ }^{6} 5$ Hermas's initial encounter with the woman, moreover, is preceded by Hermas expressing his concern that his sins are

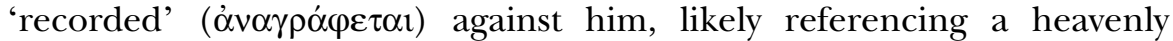
book that archives the deeds of humans. ${ }^{66}$ Hermas's anxiety over this text eventually leads to the lady comforting Hermas that, pending their full repentance, he and his family's names 'will be recorded

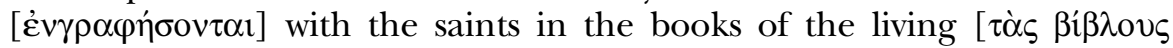
$\tau \hat{\imath} \varsigma \zeta \omega \eta \bar{\varsigma}]^{\prime} .{ }^{67}$ In this way, the Shepherd constructs a heavenly library, containing books on human deeds, the 'books of the living', and multiple books of divine knowledge. Books emerge in the Shepherd, therefore, as both a medium through which heavenly secrets are revealed to humans, as well as the original and sanctified format by which divine knowledge materialises. The Shepherd here manifests what Steven Johnstone refers to as the 'objectification' of the book: a trend in the Hellenistic and Roman eras toward valuing the book not only for its content, but also for its form. ${ }^{68}$

In light of the Shepherd's heightened valuation of books, it is significant that the text positions Hermas as having privileged access to heavenly texts. As noted previously, ancient book-copying networks typically formed along lines of friendship; Hermas's ability to borrow books from the elderly woman, therefore, establishes him as a special friend of the heavenly Church. Thus, the portrayal of Hermas's scribal activities authenticates his role as a prophetic medium and authorises the textual knowledge that he produces (i.e., the Shepherd), while also providing a heavenly model for the textual network that Hermas wishes to establish among Christian communities. As Judith Lieu puts it, 'the [Shepherd of Hermas] authenticates itself in its textuality. Indeed, since the lady it encodes is the church, church and text authenticate each other' ${ }^{69}$ The dual authentication of the Shepherd and the Church, in turn, also validates Hermas's role as scribal prophet: 'Hermas simultaneously ascribes power to texts and maintains a power over the text.' ${ }^{\circ}$

65 Vision 1.2.2; 2.1.3; Osiek, Shepherd of Hermas, 52.

66 Vision 1.2.1.

${ }_{67}$ Vision 1.3.2. For discussion see Robin Lane Fox, 'Literacy and power in early Christianity', in Alan Bowman and Greg Woolf (eds), Literacy and power in the ancient world, Cambridge 1994, 126-48 at p. 133 .

68 Steven Johnstone, 'A new history of libraries and books in the Hellenistic period', Classical Antiquity xxxiii (2014), 347-93 at p. 349. ${ }^{69}$ Lieu, Christian identity, $5^{1 .}$

$7^{\circ}$ Haines-Eitzen, Guardians of letters, 6. 
The Shepherd's construction of the transmundane network of heavenly lenders and earthly scribes, with Hermas at its centre, prompts a reconsideration of Hermas's self-presentation as a revelatory scribe. As part of his initial revelation, Hermas struggles in discerning the 'syllables' of the little book, having to resort to 'letter-by-letter' copying. For a text that otherwise emphasises the general importance of textual transcription for heavenly revelation, it is, at first glance, admittedly odd that Hermas is here portrayed as a rather ineffective scribe. Yet, as noted by Jonathan Soyars, Hermas's detailed copying here may function to underscore the accuracy of Hermas's transcription, assuring his audience that he has preserved the heavenly text's integrity down to the very last letter. ${ }^{7^{1}}$ In the context of ancient book production and copying, this was a necessary reassurance. The copying of ancient texts was unregulated and haphazard. $7^{2}$ Ancient writers frequently complain about the adulteration of texts by copyists, and recurrent corruptions in the earliest manuscripts of Christian literature confirm that such books were not copied under tightly regulated circumstances. 73 Thus, Hermas's detailed copying underscores the accuracy of his transcription, while simultaneously distancing him from any charges of corruption or compositional invention of the material that he transmits. 74 The scene likewise accentuates the revelatory potential of scribal work - since heavenly knowledge is transmitted in book form, it is the skill of accurate copying that will be the most valuable in helping the Church access the divine archive. In doing so, Hermas locates the task of revealing divine knowledge in the work of ancient scribes and copyists.

\section{Hermas the auditor}

Hermas's heavenly interlocutors stress that his transcriptions are destined for public dissemination and reading. As part of the elderly lady's instructions to Hermas, for example, she explicitly directs Hermas, alongside others, to read the prophetic works to various segments of the Christian

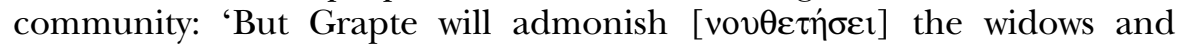

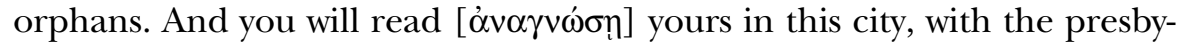
ters who lead the church.'75 This aligns well with the woman's more

$7^{1}$ Soyars, Shepherd of Hermas, 37.

$7^{2}$ Harry Gamble, 'The book trade in the Roman Empire', in Charles E. Hill and Michael J. Kruger (eds), The early text of the New Testament, Oxford 2012, 23-36 at p. $3^{0 .}$

73 Idem, Books and readers, 74, 123.

74 Lane Fox, 'Literacy and power', 132; Soyars, Shepherd of Hermas, 37. On the ancient distinction between copying and composition see Raffaella Cribiore, Writing, teachers, and students in Graeco-Roman Egypt, Atlanta, GA 1996, 10-11.

75 Vision $2 \cdot 4 \cdot 3$. 
general commands that Hermas 'tell everyone' about his revelations and speak his prophecies 'in the ears of the saints'. $7^{6}$

The explicit invocation of oral proclamation makes clear that, for the Shepherd, Christian reading cultures were to comprise not only personal reading and copying of books, but communal reading and auditing. This connection surfaces again in Vision 5, when Hermas summarises his scribal activity in an apparent aside to his audience: 'And so I wrote the commandments and parables, just as he commanded me. If then, after you hear them, you keep them and walk in them and accomplish them with a pure heart, you will receive from the Lord everything he promised you.' 77 Here Hermas combines his own process of writing with the listening of the audience, thus constructing his transcribed revelation as texts designed for communal reading.

Other elements of the Shepherd suggest a context of oral proclamation. Vision 3 includes a direct address to 'you who lead the church and sit in its chief seats', invoking a communal gathering of church leadership. $7^{8}$ Hermas at times addresses his audiences in the plural, using 'brothers' as a common identifier for what he apparently imagines as a crowd of listeners.79 In similar fashion, Hermas's heavenly interlocutors sometimes engage in direct speech to their 'listeners': 'But I, the angel of repentance, say to all of you who have this schismatic thought', ${ }^{80}$ and elsewhere, 'I, the angel of repentance, say to you who are like this' ${ }^{8}{ }^{1}$ Carolyn Osiek has also noted that the text frequently switches without comment between the use of the second person singular (in address to Hermas) and the second person plural (in an apparent address to a listening audience). ${ }^{82}$ As a final point, Hermas's heavenly mediators constantly exhort him to 'hear now' and 'listen', 83 a feature which not only positions Hermas an auditor, but will have lent itself to easy adaptation for oral proclamation in communal settings.

In this way, the Shepherd constructs a Christian culture of reading that centred on the public reading of texts within communal settings. As noted by Gamble, 'the public reading of texts was far more common in antiquity than it is today', and 'even among the literate, it was as common to be read to as to read for oneself'. ${ }^{8}$ Importantly, the communal reading of texts was an integral part of ancient textual production; GrecoRoman writers would often hold a recitation among close friends when

$7^{6}$ Parable 10.4.2, cf. 10.3.2; Vision 3.3.2. $\quad 77$ Vision 5.7. $\quad 7^{8}$ Vision 3.9.7.

79 Vision 3.10.3; Osiek, Shepherd of Hermas, $15 . \quad 80$ Parable 9.23.5.

${ }^{81}$ Parable 9.24.4, cf. 9.33.1, and Osiek, Shepherd of Hermas, 15.

82 Osiek, Shepherd of Hermas, 86, 96-7; cf. Reiling, Hermas and Christian prophecy, 161. See, for example, Visions $2.2 .7 ; 3.3 .5 ; 3.10-13 ; 11.1-2$. See also discussion above.

${ }^{83}$ See, for example, Vision 3.8.3; Commandments 6.2.1; 8.4-8; 12.1.3; Parables 8.6.4; $9.14 .5 ; 9.30 .1 ; 9.33 .3$.

${ }_{4}$ Gamble, Books and readers, 204-5. 
they had composed a new text, in order to solicit feedback before distributing to a wider audience. ${ }^{85}$ Thus, reading and aural culture were tightly intertwined in Roman literary cultures, and this also applied to early Christian reading cultures. The communal reading and interpretation of authoritative texts was a common element of Christian gatherings by the time the Shepherd was composed in the mid-second century CE. ${ }^{86}$ In this way, 'reading in the ancient world was a communal and performative act', which, for most attendees, will have consisted of aural engagement with collective readings of written texts. ${ }^{87}$

By the end of the second century, there existed in early Christian communities an official office of the 'lector', who specialised in reading (and perhaps interpreting) authoritative texts in the presence of the community. ${ }^{88}$ It is unclear if such an office existed at the time of the Shepherd's composition. Even so, the narrative clearly imagines that certain figures, including Hermas as well as Grapte, will take on this role for certain segments of the community. ${ }^{89}$ In such a way, the Shepherd implies that, at least in the case of Hermas, those involved in the copying and distribution of the text should make it known to fellow Christians through a communal reading. As noted already, the assignment of reading to figures such as Hermas and Grapte will have accorded them an important role in explaining and interpreting the text at hand.$^{\circ}$ In this way, the Shepherd's construction of a network of book-lending and copying will have had important ramifications for formulating predominant beliefs and practices within the Christian community.

The centralisation of oral proclamation has ramifications for the Shepherd's broader construction of the Christian community. It is notable, for example, that as part of the woman's interpretation of the church tower in Vision 3, wavering Christians are described as those who 'have heard the word' and yet not remained faithful..$^{11}$ In the commandments, upright Christians are consistently identified as those who have 'heard' the commandments and heeded their lessons..$^{2}$ In Vision 1, moreover,

\footnotetext{
${ }^{8} 5$ Johnson, Readers, $49-56$. Dan Nässelqvist has suggested such a context for understanding the multiple editions of the Shepherd: Public reading, 66.

${ }^{86}$ Valeriy A. Alikin, The earliest history of the Christian gathering: origin, development and content of the Christian gathering in the first to third centuries, Leiden 2010, 148; Gamble, Books and readers, 205-8; Larry Hurtado, 'Manuscripts and the sociology of early Christian reading', in Hill and Kruger, The early text of the New Testament, 49-62 at p. 53. For ancient witnesses to communal reading in Christian gatherings see Justin Martyr, I Apology 67; 1 Timothy iv.13; Rev. i.3; Colossians iv.16; 1 Thessalonians v.27.

87 Matthew D. C. Larsen, Gospels before the book, Oxford 2018, 62.

88 Gamble, Books and readers, 21 8-19; Alikin, Earliest history, 178.

89 Vision $2.4 \cdot 3$.

$9^{\circ}$ See above; cf. Gamble, Books and readers, 227; Soyars, Shepherd of Hermas, 49.

$9^{1}$ Vision $3 \cdot 7 \cdot 3$. 
the elderly woman commands Hermas to 'be a hearer and hear the glories

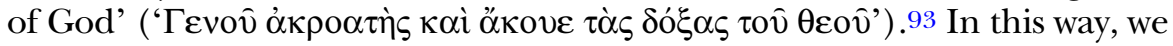
can see how the Shepherd constructs the Christian faithful not only as groups of readers and scribes, but also as communities of hearers - those who listen and engage with books in communal settings. 94

As a final point, the Shepherd's centralisation of oral readings might help explain an otherwise perplexing element of the text: the portrayal of Hermas as a rather foolish and overly inquisitive 'auditor' of his prophetic mediators. Hermas constantly fails to understand the prophecies he receives, which frequently lead to rounds of pestiferous questioning. 95 In commandment 4, for example, Hermas asks that the Shepherd 'bear with me for a few more words, since I understand nothing ... Give me insight, for I am extremely senseless and comprehend nothing at all'. $9^{6}$ Similarly, after asking for details regarding his great vision of the tower, Hermas proclaims, 'I have to ask you everything, Lord ... because I can grasp nothing at all.' 97 These passages, despite their rather negative portrayal of Hermas, serve important narrative functions in the Shepherd. Diane Lipsett has argued, for example, that these exchanges encourage 'act[s] of self-examination and relentless questioning' that ultimately contribute to Hermas's personal 'transformation' $.9^{8}$ I would note also that this self-examination and inquisitiveness construct Hermas as an interested listener who, despite occasional criticisms from his interlocutors, persistently seeks to understand the revelations read to him. This reading receives explicit support elsewhere: 'Do not try to comprehend what is beyond your power', the Shepherd exhorts Hermas, 'but ask the Lord for the understanding necessary to comprehend these things.' 99 Similarly, the elderly woman in Vision 3, after a round of questioning from Hermas, responds, 'I have told you already ... and you keep seeking; it is by seeking, therefore, that you find the truth.' ${ }^{100}$ In this way, the Shepherd ritualises engaged listening as the appropriate response to oral proclamations of Christian prophecy. The processes of revelation and reading,

93 Vision $1 \cdot 3 \cdot 3$.

94 For more on the centrality of hearing to early Christian piety see Carol Harrison, The art of listening in the Early Church, Oxford 2013.

95 See, for example, Commandment 10.1.2-3. For discussion see Miller, Dreams in late antiquity, 141 .

$9^{6}$ Commandment 4.2.1.

97 Parable 9.14.4. For additional examples see Vision 2.3.1; Parable 5.3.2; Parable $5 \cdot 5 \cdot 1$; Parable $6.4 \cdot 3$.

$9^{8}$ B. Diane Lipsett, Desiring conversion: Hermas, Thecla, Aseneth, Oxford 201 1, 41-2, 5 2; cf. Chris Keith, 'Urbanization and literate status in early Christian Rome: Hermas and Justin Martyr as examples', in Steve Walton, Paul R. Trebilco and David W. J. Gill (eds), The urban world and the first Christians, Grand Rapids, Mi 201 7, 187 204 at p. 198.

99 Parable 9.2.6, cf. 5.4.3; Parable 9.10.5.

${ }^{100}$ Vision $3 \cdot 3 \cdot 5$. 
according the Shepherd, are dialogical, dependent not only on the tasks of scribes and readers, but also on the engaged curiosity of the listener. ${ }^{101}$

\section{Hermas the freedman}

Through the character of Hermas, the Shepherd constructs a Christian reading culture centred on the scribes, readers and auditors of early Christian communities. The book, as privileged depository of heavenly insight, forms the foundation for the revelation of divine knowledge. The scribes and readers of the Christian community, in turn, emerge as essential components in the transcription and interpretation of textualised knowledge, while Christian auditory 'reading' serves as the essential practice by which 'everyday' Christians gain divine insight. By placing textualised knowledge and reading at the centre of Christian piety, the Shepherd authenticates its own revelatory medium, accentuates the reliability and authority of Hermas, enacts a private network of scribes and readers to promulgate its revelations and ritualises the aural engagement by which everyday Christians will encounter the text. Through book production, dissemination and consumption, therefore, the Shepherd constructs a reading culture whereby its textualised revelations will become a centrepiece of Christian communal life.

If the textual reception and material remains of the Shepherd are any indication, Hermas was successful in promoting just such a reading culture. ${ }^{102}$ The Shepherd became one of the most popular early Christian texts of the first few centuries, enjoying a wide distribution across the Mediterranean and translation into several languages. ${ }^{103}$ What is more, the Shepherd seems to have spread rather quickly: while it was likely composed in Rome around the mid-second century, there is evidence for its spread to Egypt, North Africa and Gaul by the late second and early third centuries. ${ }^{104}$ It is possible, therefore, that the text's promotion of its own copying and reading directly contributed to its wide dissemination. ${ }^{105}$

The successful 'afterlife' of the Shepherd provides an opportunity for considering the potential contexts that gave rise to its uniquely selfreflexive approach to the construction of an early Christian reading

${ }^{101}$ For more on active and engaged listening as part of the reading cultures of antiquity see Larsen, 'Listening with the body', and Johnson, Readers, 202.

${ }^{102}$ Lane Fox, 'Literacy and power', 132-3.

103 Osiek, Shepherd of Hermas, 1; Brox, Der Hirt, 55-6; Malcolm Choat and Rachel Yuen-Collingridge, 'The Egyptian Hermas: the Shepherd in Egypt before Constantine', in Thomas J. Kraus and Tobias Nicklas (eds), Early Christian manuscripts: examples of applied method and approach, Leiden 2010, 191-212 at p. 191.

${ }^{104}$ Gamble, Books and readers, 82, 109 ,

105 Brox, Der Hirt, 107; Gamble, Books and readers, 109. 
culture. Why did the Shepherd, distinctively among ancient sources, enumerate its own transmission and objectification as a book? ${ }^{106}$ One potential explanation lies in the self-presentation of Hermas, the text's apparent author. ${ }^{107}$ According to the Shepherd, Hermas was a freedman, or manumitted slave. ${ }^{108}$ Hermas's background as a slave-then-freedman could explain his ability to read and write, as well as his knowledge of book copying practices: slaves and freedpersons often served as scribes and readers on behalf of wealthy Romans. ${ }^{109}$ Enslaved persons, for example, regularly worked as 'lectors' (i.e., readers of literary works) at elite Roman symposia, copied written works (including letters, literary works and administrative documents), and even sometimes composed texts on behalf of their masters or patrons. ${ }^{110}$ Freedpersons typically continued to perform the work they did as slaves, often on behalf of their former masters. ${ }^{11}$ For this reason, slaves and freedpersons dominated the ranks of the main literary professions in the Roman Empire, including copyists, librarians, booksellers and lectors. ${ }^{112}$

Though the Shepherd is not forthcoming about Hermas's professional background, ${ }^{113}$ it is possible that he was a copyist or bookseller. ${ }^{114}$ We know of other freedpersons who used their literary skills to make their post-manumission living, ${ }^{115}$ and Hermas's self-presentation as scribe and lector could reflect this background. ${ }^{16}$ It is also noteworthy that the

${ }^{106}$ Gamble has noted that it is rare to find explicit discussions of book production in ancient literature: Books and readers, 42 .

${ }^{107}$ The relative accuracy of Hermas's autobiographical testimony has been the subject of intensive scholarly debate. Here I am not primarily interested in considering whether such details are entirely accurate, but how the text's self-presentation of its author may coincide with its concurrent construction of Christian reading cultures. For a recent overview of various proposals regarding Hermas's background see Weiss, 'Hermas' "Biography".

${ }_{108}$ Vision 1.1.1; Osiek, 'Shepherd of Hermas in context', 117 , and Rich and poor in the Shepherd of Hermas: an exegetical-social investigation, Washington, DC 1983, 130-2.

109 R. H. Barrow, Slavery in the Roman Empire (1928), London 1968, 61; J. Albert

Harrill, The manumission of slaves in early Christianity, Tübingen 1995, 47; Nässelqvist, Public reading, 92.

110 Keith Bradley, Slavery and society at Rome, Cambridge 1994, 62-3.

111 Ibid. 65; Henrik Mouritsen, The freedman in the Roman world, Cambridge 2011 , 221.

112 Barrow, Slavery in the Roman Empire, 61; Gamble, Books and readers, 86; HainesEitzen, Guardians of letters, 7-8.

113 For potential references to Hermas's background see Visions 1.1 .1 ; 1.3 .1 ; 2.3.1;

3.6.7; 4.1 .2 ; Parable $4.5^{-7}$. On previous proposals regarding Hermas's professional background see Weiss, 'Hermas' "biography".

${ }^{114}$ Keith, 'Urbanization and literate status', 199.

115 Mouritsen cites the example of C. Stertinius Orpex, the scriba librarius of

C. Stertinius Maximus: Freedman, 235.

${ }_{116}$ Osiek, 'Shepherd of Hermas in context', 1 22; Weiss, 'Hermas' "biography", 195 . 
name Grapte, used in reference to one of Hermas's appointed lectors, ${ }^{11} 7$ is elsewhere attested as predominantly used among slaves and freedwomen, including enslaved secretaries. ${ }^{118}$ Even if Hermas and Grapte were not booksellers or professional copyists, however, it is significant that, as a freedperson, Hermas centres the essential work of divine revelation in the roles of copying and public reading, tasks that slaves and freedpersons typically performed.

The Roman system of slavery highlighted the corporeal nature of slave labour. Elite Romans often distanced themselves from lower-class citizens and enslaved persons by their ability to opt out of difficult labour that taxed the body. ${ }^{19}$ As Michele Kennerly puts it, there was a 'cross-indexical' connection between one's bodily labour and one's place within Roman society. ${ }^{120}$ The labour of ancient scribes and copyists was experienced and characterised as difficult and arduous, ${ }^{121}$ thus perpetuating its association with lower-class Romans. It is possible that the absence of discussion in antiquity of book production stems from the associations of such processes with the manual labour of underprivileged Romans. ${ }^{122}$ In the Shepherd's narrative presentation, however, scribes go from 'unnamed and uncredited' figures to the centrepieces of Christian revelatory reading culture. ${ }^{123}$ In this way, the Shepherd of Hermas interrupts the 'cross-indexical' connection between devalued labour and devalued social standing by making the toil of scribe and lector a focal point of Christian piety. ${ }^{124}$ The authority over texts granted to scribes and lectors

117 Vision 2.4.3.

118 Osiek, Shepherd of Hermas, 59; Haines-Eitzen, Guardians of letters, 44. It is noteworthy that the name Grapte $(\Gamma \rho \alpha \pi \tau \eta \dot{)})$ is a feminine vocative form of $\gamma \rho \alpha \pi \tau-o$ s, $\dot{\eta}$, óv ('marked as with letters, written', s.v. LSJ); the vocative of the word relating to the slave's main task was sometimes used as a personal name for the slave: Sandra R. Joshel and Lauren Hackworth Petersen, The material life of Roman slaves, Cambridge 2014, 227 n. 73. Since the name Grapte appears predominantly among slaves and freedwomen, it is possible that it was a name given to slaves who performed clerical tasks.

119 Jennifer A. Glancy, Slavery in early Christianity, Oxford 2002, 3; Bradley, Slavery and society, 80 .

${ }^{120}$ Michele Kennerly, Editorial bodies: perfection and rejection in ancient rhetoric and poetics, Columbia, SC 2018, 205.

${ }^{121}$ Bruce M. Metzger and Bart D. Ehrman, The text of the New Testament: its transmission, corruption, and restoration, $4^{\text {th }}$ edn, Oxford 2005, 28-9.

${ }^{122}$ Gamble, Books and readers, 42.

123 On the 'unnamed and uncredited' status of scribes see Kennerly, Editorial bodies, 211.

${ }^{124}$ My hypothesis here fits well with other distinctive elements of the Shepherd. Several commentators have noted, for example, that the Shepherd's parable of the vineyard, which narrates the manumission of a slave in exchange for his good works, reflects an abiding concern within the text for slaves and other dispossessed peoples: Parable $5.2-11$. See also Commandment 8.10 , which seemingly encourages the ransoming of 
within the Shepherd's idealised portrait, in turn, will have afforded such Christians substantial influence within a community that increasingly shaped its identity around its interpretation of written texts. ${ }^{125}$ Put another way, "power exercised over texts allows power to be exercised through texts'.126 Through its distinctive highlighting of the reading, copying and auditing of texts, therefore, the Shepherd of Hermas provided a potential path toward social prestige and cultic influence for persons who typically resided at the margins of ancient Roman society.

slaves or prisoners (Osiek, Shepherd of Hermas, 130), as well as Parable 1.8, which exhorts Christians to 'purchase' afflicted souls (Harrill, Manumission of slaves, 1 79). For discussion on these points see Glancy, Slavery, 105, and Mary Ann Beavis, 'The Parable of the slave, son, and vineyard: an early Christian freedman's narrative (Hermas Similitudes 5.2-11)', Catholic Biblical Quarterly lxxx (2018), 655-69.

${ }_{125}$ On the authority of texts in early Christianity see Haines-Eitzen, Guardians of letters, 124, and Lieu, Christian identity, 27-61.

${ }^{126}$ Bowman and Woolf, Literacy and power, 8, emphasis original. On this point see also Haines-Eitzen, Guardians of letters, 127. 